\title{
The Sand Creek Massacre
}

\author{
Asa M. Kerr, Department of History, Indiana University Bloomington
}

ABSTRACT

The 1864 massacre of Cheyenne and Arapaho Native Americans by a Colorado territorial militia regiment is investigated through a 1 genocidal lens, both as a component of the larger destruction of Native American cultures and peoples by U.S. forces and in its own specific economic and ideological context. Using the work of many other scholars in the field of genocide studies and the established definition of genocide provided by the UN Convention on Genocide, this essay initially defines how the gradual dwindling of Native American populations from the onset of European colonization through the next three centuries can be viewed as genocide. Following this groundwork, the question of culpability for the massacre is brought forth and three main categories of suspects are identified: local government and military leaders, the White settler population of Colorado, and the U.S. federal government. All three potential areas of culpability are shown to possess varying degrees of responsibility in effecting the massacre. Upon conclusion of the investigation, there is a brief discussion of possible means of reconciliation accompanied by an examination of the nature of current reconciliation efforts.

Sand Creek Massacre, Native American genocide, Native American studies, culpability

\section{BACKGROUND}

The tenor of the relationship between Euro-American inhabitants of North America and the continent's indigenous populations is most clearly indicated in the estimated 98\% decrease of Native American inhabitants, from roughly 15 million in 1500 to a meager 250,000 in 1890 (Waller, 2007, p. 21). This monumental destruction of indigenous North American populations has in recent years invited the study of many scholars in the field of Holocaust and genocide studies, who in various ways, attempt to ascertain the extent to which the population decline can be attributed to genocidal action. On the other hand, arguably because of the key role the destruction of American Indian civilization played in the formation of the United States, many scholars have attempted to portray this mass death as a result of disease and military conflict, admittedly peppered with atrocities, using the U.S. federal government's lack of a stated intent regarding Indian extermination as a factor excluding the tragedy from genocide status. This postulation is for the most part historically accurate and corresponds to the opening clause of Article II of the UN Convention on Genocide, which lists "the intent to destroy" as a necessary factor for genocide (United Nations, 1951, p. 280). However, as Alfred Cave (2010) points out, the UN definition of genocide "does not require the sanction of the state" (Cave, 2010, p. 276). Even this point is somewhat arbitrary in light of the fact that most violence perpetrated against Native Americans occurred in frontier settlements, often with the approval of state or territorial governments, far removed from federal influence.

Such is the case of the 1864 Sand Creek Massacre, in which roughly 150 Cheyenne and Arapaho noncombatants were killed by the $3^{\text {rd }}$ Colorado Volunteer Cavalry Regiment, a federally-sanctioned creation of the territorial government of Colorado (Waller, 2007, p. 36). Investigating the decimation of Indian populations as genocide necessitates an examination of Euro-American violence against specific Indian tribes in isolated instances because of the vast contextual differences between, for instance, the massacre of Pequot at Fort Mystic in 1637 and the Sand Creek Massacre some two centuries later. Similarly, following Elazar Barkan (2003), this examination will offer a "nondeterministic approach that explores the issue of genocide within a context and not against a universal yardstick" because of the vast historical, cultural, and technological differences between Sand Creek and the genocides of the $20^{\text {th }}$ and $21^{\text {st }}$ centuries (Barkan, 2003, p. 119). Primarily examining the specific ideological and economic context, at both state and federal levels, of the events at Sand Creek will allow the motives for this massacre to be further elucidated, thereby providing a nuanced understanding of each governmental sphere's 
culpability in the event. In addition, Stannard's emphasis on the importance of racism as foundational for genocide against Native Americans and Tinker's formulations concerning cultural genocide and the importance of consequences over intentionality will be especially helpful in locating the impetus for the events at Sand Creek (Barkan, 2003, p. 124). This focus on consequences over intentionality is, however, incomplete in that it satisfies itself merely with the condemnation of events without determining those who are primarily guilty for their occurrence. In order to pinpoint the cause of these events, a methodology of examining the interaction of frontier and federal narratives surrounding Sand Creek will aid in identifying the intent of these two separate forces.

Much like genocide studies itself, scholarship on Sand Creek is a relatively new field, and as a result there is minimal research on the subject. In many respects, the lack of scholarship on Sand Creek, or the three centuries of genocide inflicted upon Native Americans of which it is a part, can be attributed to what Stan Hoig (1961) termed the "enormous prejudices" of the AngloAmerican population (Hoig, 1961, p. vii). Even at the ceremonialopening of the Sand Creek Massacre National Historic Site in 2007, Ari Kelman (2013) observed in the vague and apologetic language of speeches there delivered the fact that "collective remembrance both shapes and is bound by contemporary politics" (Kelman, 2013, p. 29). Yet, even Bruce Cutler in 1930 believed the massacre constituted genocide, evincing the polarizing effect Sand Creek has had on Americans since November 1864 (Cutler, 1997, p. viii).

The general scholarly consensus has been to emphasize the local origin of perpetrators. While Kelman's (2013) recent A Misplaced Massacre does include a discussion of federal culpability, it is peripheral to the work and receives little attention. With this in mind, Kelman's (2013) text does provide a solid historiographical framework with which to investigate the degree of federal culpability, though its greatest contribution is undeniably its examination of the few and insincere contemporary attempts at reconciliation and remembrance. In addition, Hoig's (1961) work is especially effective in laying out an extensive historical context that briefly recounts U.S. federal Indian policy and more significantly shows the development of Cheyenne, Arapaho, and White relations in the Colorado Territory. While the volume of Sand Creek scholarship is minimal, its quality has laid a solid foundation upon which more knowledge can be expounded, ideally bringing collective remembrance and genuine reconciliation to the forefront of contemporary U.S. politics and culture.

Relations between the Cheyenne and Arapaho tribes and White settlers had traditionally been peaceful. In fact, it was not until 1856 that an instance of violence occurred, and this even was considerably minor (Cutler, 1997, p. 5). However, this peace would not survive the discovery of gold at Pikes Peak and the South Platte in 1858, beckoning floods of hopeful Whites to the area traditionally controlled by the Cheyenne and Arapaho (Cutler, 1997, p. 5). White pioneers came in numbers rivaling the California gold rush of 1849 and once they arrived, they built towns and stayed (Cutler, 1997, p. 5). The 1851 Treaty of Fort Laramie, which defined the Cheyenne and Arapaho domain as the vast expanse between the Arkansas and Platte Rivers, would be utterly disregarded by the gold-crazed pioneers (Cutler, 1997, p. 4). As isolated fringe groups from both cultures inflicted atrocity after atrocity on each other, feelings of mutual hatred gradually took hold, albeit more thoroughly amongst the encroaching Whites. Coloradans' fear and hatred of the surrounding Cheyenne and Arapaho undeniably culminated in the Sand Creek Massacre, in which an assembly of regional chiefs and their civilian followers who had gathered near Denver in order to declare their peaceful intent to the Coloradan government were slain in a surprise attack carried out by the hastily assembled $3^{\text {rd }}$ Colorado Volunteer Cavalry Regiment.

\section{RESPONSIBILITY OF COLORADAN TERRITORIAL GOVERNMENT}

At the forefront of those who can be considered guilty for the atrocities of Sand Creek are the Governor 
of Colorado, John Evans, and commander of the attack, Lieutenant Colonel John Chivington. These two local officials arise as those immediately guilty in part because they both hoped to lead Colorado into statehood, ideally as its first senators (Cutler, $1997 \mathrm{pp}$. 134-35). Their political ambitions would be well-served by a highly publicized defeat of Indians in battle and a step towards the eradication of the nomadic and disruptive Cheyenne and Arapaho from Coloradan lands, both of which the massacre was intended to accomplish. After the massacre, the Joint Committee on the Conduct of War's investigative report of the events corroborated this assumption when it stated regarding Chivington, "political preferment prompted him to this cowardly act...pandering to the inflamed passions of an excited population" (Wade, 1959, p. 26). The former Methodist minister and ardent abolitionist's hardline stance against Indians was indeed popular amongst a majority of Coloradans, as indicated by the local newspaper coverage of Sand Creek (Kelman, 2013, p. 9). In the words of Kelman (2013), Chivington saw himself and the near-paramilitary militia that was the $3^{\text {rd }}$ as "shock troops for expansion," clearing the way for pioneering Whites invested with a sense of manifest destiny (Kelman, 2013, p. 17). Nearly 20 years after the massacre in an 1883 speech, Chivington held fast to his belief that Sand Creek had pacified the troublesome Cheyenne and Arapaho. However, the massacre has in fact been said by many - firsthand observer George Bent among them - to have been an impetus for their alignment with the more militant Northern Arapaho and Sioux against White expansion (Kelman, 2013, p. 170). As Steve Brady, a modern Cheyenne leader, has said, Sand Creek "taught the Cheyenne People that whites would never let us live in peace" (Kelman, 2013, p. 48). Chivington's belief in the strategic military value of Sand Creek, even years after the event, indicates his fervent, blinding commitment to eradicating Indians from Colorado, his infamy preserved for posterity in his genocidal order issued to the $3^{\text {rd: }}$ "kill and scalp all... little and big... Nits make lice" (Waller, 2007, p. 27).

Similarly, Governor Evans is equally culpable in the provocation of the violence that would occur at Sand
Creek. On June 27, 1864, Evans issued a proclamation to all tribes within his jurisdiction, calling those who wished to be considered friendly to gather at the nearest military post so negotiations could begin (Wade, 1959, p. 24). It was this proclamation that motivated Cheyenne and Arapaho chiefs Black Kettle, White Antelope, and Left Hand to take council with Evans and other local officials in Denver. However on August 11, 1864, after this council, which proved to all present the peaceful intent of these chiefs, Evans impatiently abandoned his first proclamation attempting to separate hostile from peaceful tribes, and this time without notifying the Indians presented a proclamation "authorizing all citizens of Colorado, either individually or in such parties as they may organize, to go in pursuit of all hostile Indians on the plains...to kill and destroy... wherever they may be found" (Hoig, 1961, pp. 689). This is the moment at which Colorado's territorial government policy escalated from war on hostile tribes to extermination of all tribes: from isolated conflict to genocide. The bands of Cheyenne and Arapaho led by the aforementioned peaceful chiefs in their initial talks with Coloradan representatives were led to believe that peace talks were in progress, but necessitated the involvement of the federal government and would therefore take some time to resolve. Under this assumption, the Cheyenne and Arapaho set up camp at Sand Creek outside of Fort Lyon as voluntary prisoners, still maintaining their peaceful relations with whites, as George Bent reports, by "exchanging friendly visits with the garrison" (Hyde, 1968, p. 147).

Simultaneously, Evans had been petitioning the Federal Commissioner of Indian Affairs Charles E. Mix to send troops or authorize the formation of a militia in order to defend his citizens from hostile Indians. In order to accomplish this task, much exaggeration was necessary, seen in his August 10, 1864 letter to the Commissioner: "I am now satisfied that the tribes of the plains are nearly all combined in this terrible war ... It will be the largest Indian war this country ever had, extending from Texas to the British lines [Oregon]" (Hyde, 1968, p. 67). This claim was wholly inaccurate at the time it was made, yet would come to seem prophetic 
following the massacre at Sand Creek. Evans's incredible exaggeration of the situation, whether a conscious embellishment or not, was based off of earlier accounts of Indian violence that were also sensationalized.

An example of this sensationalizing convention is found in Major Colley's letter to Evans on July 26, 1864, wherein Colley reports the death of 10 men at the hands of Indians (Colley, 1959). Though the Indians responsible were likely Dog Soldiers, a militant band of Cheyenne unassociated with chiefs White Antelope and Black Kettle, Colley closes his letter saying, "As near as they can learn, all the tribes were engaged in it...I now think a little powder and lead is the best food for them" (Colley, 1959, p. 9). The day after his wire to the Commissioner, Evans received federal permission to form the $3^{\text {rd }}$ Colorado Volunteer Cavalry Regiment. Unfortunately, the only pool from which recruits could be drawn was from those local men who had not gone to fight in the Civil War, an eclectic assortment of Denver's drunks and criminals, termed a "perfect mob" by Silas Soule, one of its own commanding officers (Kelman, 2013, p. 23). Evans's deception of the peaceful chiefs of the Cheyenne and Arapaho tribes and the Commissioner of Indian Affairs locates him as the primary coordinator of the massacre.

Although Chivington and Evans both had political stakes in the Sand Creek Massacre, their hatred of and violence towards Native Americans was not solely a ploy to secure the favor of the Indian-hating public. These two local actors were just as much a part of the cultural fabric they hoped to endear themselves to; their fear and hatred of Indians commingled with their political aspirations drove them to perpetrate Sand Creek. Evans and Chivington were not masterminds who sacrificed their morality in order to advance their careers. According to Kelman (2013), Chivington buttressed his ideological hatred of Indians by citing the work of contemporary "scientists" such as Samuel Morton who posited a "polygenesis," or multiple creations of humanoid species based on skull measurements (Kelman, 2013, p. 15). This view held that Indians were an inherently violent species of human incompatible with the more civilized Whites. Such an example of the prevalent scientific beliefs of the era provides a window through which the genocidal commands of Evans and actions of Chivington can be better understood to have been firmly rooted in the ideological foundations of frontier, and more broadly, Western culture.

\section{FRONTIER IDEOLOGY IN PRINT CULTURE}

The extent to which ideological hatred of Indians, and the specific rationale behind it, was engrained in White frontier culture is indicated in the local media coverage of the events at Sand Creek. Immediately following the Sand Creek Massacre, the two major Colorado newspapers, The Rocky Mountain News and The Daily Mining Journal, both celebrated the attack as a part of a largely-imagined war, and in doing so, revealed the ideological beliefs of the White settlers of the Colorado territory. Upon hearing of the events, The Daily Mining Journal paints the commanding Colonel John Chivington as an "avenging angel" against the "Devil's own sons of the plains" (Reilly, 2011, p. 22). Furthermore, the Journal claims that if Chivington can kill 2,000 Indians, they, along with the entire population of Colorado, will praise and support him. It is important to note at this point that Chivington and the $3^{\text {rd }}$ Cavalry's initial report of Cheyenne and Arapaho casualties claimed 500-600 dead, while the actual total was closer to 150 - two-thirds of which were women and children (Reilly, 2011, p. 21). The bloodlust of frontier media is made more evident when, after Chivington failed to press his attack, the Journal laments the cessation of the campaign, which they believed could potentially allow "not a redskin between the Platte and the Republican... escape" (Reilly, 2011, p. 22). This certainly echoes a genocidal intent, indicating the widespread frontier belief in the incurable evil and savagery of their Native American neighbors.

Though a dehumanized view of Native Americans was common to frontier culture, rumors of massacre eventually began to spread through Colorado from the mouth of Silas Soule, an officer of the $3^{\text {rd }}$ who alone forbade his troops from firing upon the fleeing victims (Kelman, 2013, p. 30). The Denver-based Rocky 
Mountain News took this opportunity to remind its readers of the dangers posed by proximity to the Indians, especially to "the fair sex" (Reilly, 2011, p. 23). Preserving the purity of White femininity, so fundamental to Anglo-American society, was along with racial superiority another significant element of frontier ideology, as the News emphasizes when writing of the "gallant boys" of the $3^{\text {rd }}$ who "donned the regimentals for the purpose of protecting the women of the country by ridding it of redskins" (Reilly, 2011, p. 23). The dated concepts of chivalry that played such a large role in Southern ideology are not absent from the frontier; rather they play a key role in the justification of atrocities against Indians, who were understood by their very existence to pose a threat to the sacred space of white femininity.

Another element of frontier ideology, though arguably less-staunchly believed than the widely-held gender and racial ideologies, presents itself in the responses from the supposed Indian apologists back East to the rumored outright massacre of peaceful Indians at Sand Creek. The News argues that because of their distance from the hectic events of the frontier, the eastern elites or "high officials" cannot possibly understand the danger posed by Indians, and the atmosphere of fear and hardship that environment created (Reilly, 2011, pp. 23$4)$. In response to the allegations of massacre, initially propagated by Soule to his New England connections, the News claims the impossibility of the existence of a "friendly Indian" or "surrendered village" (Reilly, 2011, p. 23). The News' commitment to preserving a favorable image of Chivington is confirmed when they refer to him as a "rough diamond of Colorado," playing upon the regional loyalties of their readers in the face of eastern and federal Native American sympathizers (Reilly, 2011, p. 26). Yet, the Journal's reaction to the allegations was more balanced. While maintaining that, "on the question of killing these miserable, cruel fiends of hell...the people of Colorado are united as one," they believed that an official investigation, then imminent in January of 1865 under the direction of Senator James R. Doolittle, was the only possible way to determine the truth (Reilly, 2011, p. 25). So, while opposition to the intervention of federal officials was not entirely pervasive, it was bolstered by the ideological hatred of Native Americans and fear of their pollution of the female sex.

From this examination the intentionality of this genocide seems to be located within the power structure of Colorado's territorial government along with an emphatic participation and complicity of the general populace. Though offering only a narrow window, these newspapers indicate that the federal government and eastern intellectuals were largely opposed to the mass killing of peaceful Cheyenne and Arapaho Native Americans. At the root of this genocide is the impassioned hatred and fear of Native Americans engendered by frontier ideology, perpetuated by a distrust of elitist outsiders. Here, the work of James Waller (2007) is highly relevant, positing a collectivistic cultural construction as a model "relevant to understanding how ordinary people commit genocide and mass killing" (Waller, 2007, p. 173). Though not wholly a collectivistic culture as Waller describes it, the White settlers of Colorado came together around their shared racial identity and cultural traditions, finding in the nearby Indians an 'other' against which they could push back and define themselves. These intense feelings of group solidarity were likely solidified by the hardships common to frontier life. Channeling their fear and aggression towards Indians likely provided settlers a sense of psychological security, while providing us an insight into their ability to commit or condone such horrid atrocities as occurred at Sand Creek.

\section{THE FEDERAL GOVERNMENT}

Although the examination of frontier newspapers indicates that the most direct culpability for the Sand Creek Massacre lies with the local government and population, there is still one major player yet to be examined: the U.S. federal government. As Senator B.F. Wade of Ohio stated in The Joint Committee on the Conduct of War's investigation of the massacre, "Colonel Chivington...wearing the uniform of the United States...deliberately planned and executed a foul and dastardly massacre" (Wade, 1959, p. 26). Indeed, 
Chivington did play a large part in planning and accomplishing the massacre, yet he cannot, along with Evans and the White settlers of Colorado, be seen as the lone scapegoat for the atrocities. Evans was only able to form the $3^{\text {rd }}$ Colorado with the express authorization of Charles E. Mix, General Samuel R. Curtis, and the War Department (Hoig, 1961, p. 69). In the aforementioned August 10, 1864 correspondence between the two, some four months before the massacre, Mix (1959) wrote, "You will use every endeavor to keep the peace with the Indians, and it is hoped that troops will soon be placed at your disposal for that purpose" (Mix, 1959, p. 7). The vagueness of Mix's (1959) language in "keep peace with the Indians" seems to give little direction to, or place little limit on, the potential military action of troops afforded to Evans (Mix, 1959, p. 7). Union troops were never sent because of the priority taken by the Civil War, yet it is important to note that Evans requested not only federal troops but also the formation of a regiment of "hundred-day volunteers" as an alternative, likely in the knowledge that professional soldiers would not be sent west while the eastern states were in such peril (Hoig, 1961, p. 67).

However, had the Federal government sent a regiment to the Coloradans, the professionally-disciplined blue jackets would quite possibly not have assented to attacking the unarmed Native Americans at Sand Creek because of their distance from the infectious racism of the frontier ideological context. According to Bent, the officers of the $3^{\text {rd }}$ had been selected by vote and had no meaningful control over their men, who were, as 100day volunteers, anything but disciplined (Hyde, 1968, p. 148). Though it was certainly his brainchild, the creation of the $3^{\text {rd }}$ was not in the hands of Evans, and rather relied on the authorization of the federal government, which consented without a shred of reliable proof, its decision based rather on the exaggerated accounts of Evans. So, the federal government is clearly not responsible for planning the massacre, yet it did condone the formation of the $3^{\text {rd }}$, an act of administrative oversight legitimating a regiment of soldiers without providing so much as one military advisor or overseer.

A more poignant critique of the federal government's role in Sand Creek is concerned with the systemic issues of the social structure it founded and perpetuated. Samuel Teppan, who had actually served under Chivington, believed the root of U.S. and Native American conflict "rested with those highest in authority; for not having fixed and well understood policy that would have frustrated the possibility of a Sand Creek Massacre" (Kelman, 2013, p. 173). Similarly, Helen Hunt Jackson, a writer and poet from Massachusetts, wrote the monumental A Century of Dishonor in 1881, chronicling the mistreatment suffered by various Native American tribes at the hands of the U.S. government. Rather than understanding Sand Creek to be an isolated event, Jackson said it "stemmed from misguided Federal policy," a result of "one hundred years of treaty-making and treaty-breaking” (Kelman, 2013, p. 217). Her theory was quite accurate, for White gold rushers had indeed violated the Treaty of Fort Laramie in 1858, straining the otherwise amiable relationship between the Cheyenne and Whites and leading to small-scale violence between the two groups. Though not directly in charge of the men who committed the atrocities, the federal government can be viewed as culpable for endorsing a contradictory treaty policy and vesting power with the inflamed and politically ambitious Evans and Chivington. Additionally, Tony Barta (1987) remarks upon the concept of a genocidal society; although there may be official policy aimed at protecting indigenous people, as in the case of federal government-Native American relations, "a whole race is nevertheless subject to remorseless pressures of destruction inherent in the very nature of the society" (Barta, 1987, pp. 238-239). These "relations of genocide" are inherently and maybe even unconsciously formed in the social fabric of genocidal societies, those such as the frontier Coloradans who were above all concerned with acquiring and defending land as prescribed by manifest destiny (Barta, 1987, p. 238).

\section{A QUESTION OF RECONCILIATION}

The surprise assault on the Cheyenne and Arapaho at Sand Creek in 1864 was surely perpetrated by adherents to a pervasive frontier ideology, coordinated by 
politically-interested local officials who were zealous Native American haters. Yet, the federal government must share blame, partly for having authorized the directly guilty characters to act, but more significantly because of the structure and function of the society it represented and perpetuated; a society that could not merely coexist with the Native Americans on its periphery. The atrocities at Sand Creek heralded the tragic, gradual genocide of the Plains Indians that once inhabited swaths of the American West. While the ideology that once so enflamed the population has died out, the descendants of those White settlers have in many cases failed to make meaningful reparations with the Cheyenne and Arapaho community. Though full reparations are impossible, generating wider acknowledgment of the massacre in the non-Native American community through enacting memorial days and re-organizing school curriculums could have positive effects on the relationship between these communities. It has now been 150 years since the day Chivington and the $3^{\text {rd }}$ irrevocably altered Plains Indian's view of their neighbors, and though efforts such as the formation of The Sand Creek Massacre Commemoration Group and the beginning of a "Spiritual Healing Run" have been made, there is still much to be done. As Kelman (2013) writes, "upholding patriotic orthodoxy sometimes demanded collective amnesia rather than remembrance" (Kelman, 2013, p. 31). It is currently of urgent necessity that such orthodoxies that repress painful memories for the sake of preserving a clear, dichotomous narrative be reexamined and prevented from further obstructing active acknowledgement, and, if possible, reconciliation.

\section{ACKNOWLEDGMENTS AND CORRESPONDENCE}

The author would like to thank Heath Spencer for his continued support and guidance during each stage of the research project

All correspondence concerning this article should be addressed to Asa M. Kerr at asakerr@umail.iu.edu

\section{REFERENCES}

Barkan, E. (2003). Genocides of indigenous peoples: rhetoric of human rights. In R. Gellately Editor \& B. Kiernan (Eds.), The specter of genocide: mass murder in historical perspective (pp. 117-140). Cambridge, UK: Cambridge University Press.
Barta, T. (1987). Relations of genocide: land and lives in the colonization of Australia. In I. Wallimann and M. N. Dobkowski (Eds.), Genocide and the modern age: etiology and case studies of mass death (pp. 237-253). New York, NY: Greenwood Press.

Carrol, J.M. (1985). The Sand Creek massacre: a documentary history 1865-1867. Mattituck, NY: Amareon Ltd.

Cave, A.A. (2010). Genocide in the Americas. In D. Stone (eds.), The historiography of genocide (pp. 273-295). New York, NY: Palgrave Macmillan.

Colley, S.G. (1959). Letter of Major Colley to Governor Evans. In Sand Creek papers: testimonies and statements reflecting facts concerning the killing of Cheyenne and Arapaho Indians on November 29, 1864 by the third Colorado volunteers (pp. 9-11). Black Forest, CO: Black Forest Bookman.

Cutler, B. (1997). The massacre at Sand Creek: Narrative voices. Norman, OK: Oklahoma University Press.

Hyde, G.E. (1968). Life of George Bent: written from his letters. Norman, OK: Oklahoma University Press.

Hoig, S. (1961). The Sand Creek massacre. Norman, OK: Oklahoma University Press.

Kelman, A. (2013). A misplaced massacre: Struggling over the memory of Sand Creek. Boston, MA: Harvard University Press.

Mix, C.E. (1959). Letter from the Commissioner of Indian Affairs to Governor Evans. In Sand Creek papers: testimonies and statements reflecting facts concerning the killing of Cheyenne and Arapaho Indians on November 29, 1864 by the third Colorado volunteers (p. 7). Black Forest, CO: Black Forest Bookman.

Reilly, H.J. (2011). Bound to have blood: Frontier newspapers and the Plains Indian wars. Lincoln, NE: University of Nebraska Press.

Sand Creek papers: testimonies and statements reflecting facts concerning the killing of Cheyenne and Arapaho Indians on November 29, 1864 by the third Colorado volunteers (1959). Black Forest, Colo.: Black Forest Bookman.

United Nations. (1951). Convention on the prevention and punishment of the crime of genocide (UN Publication No. 1021). Retrieved from: https://treaties.un.org/doc/Publication/ UNTS/Volume\%2078/volume-78-I-1021-English.pdf

Wade, B.F. (1959). The joint committee on the conduct of war. In Sand Creek papers: testimonies and statements reflecting facts concerning the killing of Cheyenne and Arapaho Indians on November 29, 1864 by the third Colorado volunteers (pp. 24-26). Black Forest, CO: Black Forest Bookman.

Waller, J. (2007). Becoming evil: how ordinary people commit genocide and mass killing. Oxford, UK: Oxford University Press. 